Boise State University

ScholarWorks

Public Policy and Administration Faculty

Publications and Presentations

Department of Public Policy and Administration

9-1-2009

\title{
The Effect of Frequent Managerial Turnover on Organizational Performance: A Study of Professional Baseball Managers
}

Gregory C. Hill

Boise State University

\section{(c) $(1) \Theta \Theta$}

This is an author-produced, peer-reviewed version of this article. (C) 2009, Elsevier. Licensed under the Creative Commons AttributionNonCommercial-NoDerivatives 4.0 International License (https://creativecommons.org/licenses/by-nc-nd/4.0/). The final, definitive version of this document can be found online at The Social Science Journal, doi: 10.1016/j.soscij.2008.11.001 


\title{
The Effect of Frequent Managerial Turnover on Organizational Performance: A Study of Professional Baseball Managers
}

\author{
Gregory C. Hill, Ph.D. \\ Boise State University \\ 1910 University Dr. \\ Boise, Idaho 83725-1935 \\ Ph. 208.426.2917 \\ Fax. 208.426.4370 \\ greghill@ boisestate.edu
}

\begin{abstract}
This analysis is designed to study the question of a manager's contribution to the organization, particularly in terms of uncertainty related to managerial succession. The theory of managerial succession, which is the replacement of one public manager with another, suggests a negative relationship between change and organizational performance. Organizations' decision to change managers more often exacerbates the negative effect on performance. The hypotheses are tested using baseball managers as proxies for public managers, as they perform similar duties, have similar goals, and operate under similar constraints. The results suggest that managerial succession has a negative effect on organizational performance. Frequent succession events also have a negative effect on performance, although the relationship is non-linear in nature.
\end{abstract}

"Managing is getting paid for home runs someone else hit." Casey Stengel, 1890-1975

It is difficult to overstate the recent fervor with which public management theories are being developed, analyzed, and verified. On the one hand, normative and positive theories alike are appearing in mainstream public administration and political science journals. On the other hand, there is much work left to be explored. The theory of managerial succession is designed to study the question of a manager's contribution to the organization, particularly in terms of uncertainty related to succession events. This analysis attempts to build upon this foundation and explore the effects of frequency on managerial succession on organizational performance.

In an effort to strengthen the theoretical and empirical arguments of managerial succession (Boyne and Dahya 2002, Hill 2005), this study is designed to test a specific phenomenon that has not yet appeared in the public management literature, namely the frequency of executive succession. Is there a time component to the effects of succession? What happens to the performance of organizations that have multiple succession events over time? Is there a "grace period" in which a new manager is allowed to fledge along before the organization makes another managerial change? Do organizations that change managers more often suffer lower performance, or are frequent changes invigorating to the line workers? All of these questions are affected by an organization's decision of how often to change managers.

This analysis, however, goes beyond the constraints of the public manager. Public administration is burdened by the performance indicator. What is public performance? Can it be measured? Can it be generalized? In an effort to address these constraints while still staying true to the nature of the public manager, a proxy measure for the public manager is employed; baseball managers. Laid out below is a framework that suggests that public managers and baseball managers are not so different, and by using data from Major League Baseball, we can produce some empirical analyses that exceed the capacity of most public management datasets.

Using baseball managers as a proxy for public managers certainly has its limitations. First, and most obvious, baseball managers are not public managers. However, public managers and baseball managers really are not that 
different (Grusky 1963; Gamson and Scotch 1964; Allen, Panian, and Lotz 1979). Both are charged with producing results that are above the expected norm with the resources they have. By way of comparison, baseball players sign contracts with owners, independent of on-the-field managers. In the same vein, civil servants have rights and protections that exist regardless of who manages them. ${ }^{1}$ Continuing the similarities, neither baseball managers nor public managers have unilateral authority to fire their subordinates. In both baseball and the public sector, managers are in part hired and fired by the results of their subordinates. Finally, in both cases certain managers tend to be more sought after than others.

Second, the tests using the baseball data are only addressing issues of internal management. ${ }^{2}$ This is an important distinction, particularly in terms of the ability, or inability, to test for networking. Much of the theoretical and empirical analyses of public management and performance have centered on the influence of networking on performance (Agranoff and McGuire, 2003; Bogason and Toonen, 1998; Bressers, O'Toole, and Richardson, 1995; Goldsmith and Eggers, 2004; Klijn, 1996; Mandell, 2001; Meier and O’Toole, 2005; Milward and Provan, 2000; O'Toole, 1997; Peterson and O'Toole, 2001; Rhodes, 1997). Although the empirical analysis provides mixed evidence that networking is affected as a consequence of succession, or that networking helps to soften the blow, it is still a theoretically viable discussion. However, a theory of baseball managers and networking differs slightly from the theory of public managers and networking. In other words, baseball managers are not likely to rely on other managers, professional organizations, and community elites to influence their performance; these duties are likely to be more applicable at the general manager, or at the level of the appointed official. The general manager of a baseball organization is traditionally responsible for filling the seats in the stadium, working television and radio relations, as well dealing with professional organizations such as the players' union and the umpires' union. A test for the effects of networks on influencing performance, then, is not theoretically appropriate or necessary for this analysis. The focus here will be solely on the effect of succession on the new manager's influence on the internal structure, or the runs scored by the team and the number of games the team wins.

\section{Management Literature}

The study of public managers is not new. Woodrow Wilson said, "It is the object of administrative study to discover, first, what government can properly and successfully do, and, secondly, how it can do these proper things with the utmost possible efficiency and at the least possible cost either of money or of energy" (Wilson 1887, 197). Wilson establishes early in the study of public administration the importance of management and the role it plays in governmental provision of services. Wilson, Weber (1946) and Taylor (1911) all insinuate that organizations are rigid, and managing them is a rigid, machine-like task. As theories on organizational management evolve however, the rigid management theory has evolved into more fluid management, suggesting that managers have discretion in the way they supervise their organization, whether the discretion is at the organizational level (Huber and Shipan 2002) or directly from upper management (Morgan, 1998; Denhardt, 2000). The less rigid view of management gives managers the opportunity to be more responsive in their provision of services. It is important to the organization as well as to society as a whole that government develops ways to provide services effectively and efficiently. In fact, as Cook asserts, public agencies have traditionally been thought of as nothing more than "subordinate instruments or servants of the public will" (1996, 3). However, Cook goes on to argue that, "public administrators and their organizations not only help to serve the goals, wants, and needs of the people; they also help to determine those goals, wants, and needs, in complex and sometimes worrisome ways" (1996, 3). Clearly Cook, and many other post-modern scholars are convinced that public managers affect organizational performance both through authoritative means and informal influence.

\section{Governance}

It is the pursuit of governance to determine how the public sector can continue to provide services across a broad range of arenas that satisfy the public good (Lynn, Heinrich, and Hill, 2001). The management of those who are

\footnotetext{
${ }^{1}$ Protection was started, at least, with the Pendleton Civil Service Reform Act of 1883. This is roughly the same time period (1871) in which baseball became mainstream and starting keeping statistics (James 2001). James reports one of the first baseball statistics interestingly, was the batting average (.295) of the Boston Red Stockings.

${ }^{2}$ The assumption of internal management is based upon the extant literature which argues that there are two components to managing an organization; internal and external (Meier and O'Toole 2002a). Internal management is understood to mean hierarchical relationships, and external management is relations outside the direct authoritative control of the manager, often referred to as network.
} 
charged with providing services to the public has a lot to do with the effectiveness of the provision of services. This study is referred to as "governance." Governance can be defined as; "regimes of laws, administrative rules, judicial rulings, and practices that constrain, prescribe and enable government activity" (Lynn, Heinrich, and Hill, 2001, 3) where "activity" is defined as the delivery of the goods and services the government is charged with providing. In order to deliver the goods and services, organizations are designed so that the onus of this delivery falls upon the managers.

To efficiently study the impact managers have on the organization, it is important to define management as a concept. "Management," in the literature, has a wide variety of connotations and definitions (see Rainey 1997). Lynn's $(1995,2)$ definition of the public manager seems apropos;

An identifiable group of actors in political life, called for convenience "public managers," collectively perform a significant part of the executive function in government. Public managers are the human capital of the government's executive capacity. The contributions of these actors are shaped and constrained by diverse authorities: constitutions, statutes, administrative arrangements and practices, court orders, and political custom.

Finally, the theory of managerial succession, first posited by Boyne and Dayha (2002) suggests that managerial succession has an impact on organizational performance, but that impact is mitigated by three conditions: the means, motives, and opportunities of the replacement manager. The relationship they posit between performance, succession, and managerial conditions is hierarchical in nature, and they even go so far as to posit hypotheses, but do not provide any empirical justification for their claims. Hill (2005) adds to the theory by further refining the theory into short-term, immediate impacts and long-term impacts. He finds that while the short-term affects of managerial succession will negatively impact performance, the long-term affects are positive.

In order to trace out the logic of the argument, some assumptions about the replacement manager are necessary. The assumption is that on average, the organization replaces the old manager with a better manager. It is unlikely that data exist to support such a claim, but while there is tremendous uncertainty in the hiring process, the assumption is that the organization at least believes they are hiring a better manager than the one they left behind. This is may not always be the case, such as in terms of voluntary replacements or retirements.

\section{Justification}

The time frame required to run an analysis of multiple succession events in multiple organizations over time requires a database that exceeds the ability of most data sets available. As such, this study relies upon data from Major League Baseball managers and organizations. The data cover a span of 25 years, from 1979-2003, with 26 teams, providing 650 observable years (Forman 2000). Although baseball is a complex, private sector entity, the intent is to test a manger's contribution to performance in the event of managerial turnover, and the use of baseball numbers can be readily generalized to both the private and public sectors.

This study is not the first attempt to use baseball (or other sports) as a conduit for the application of public managerial questions. In fact, the unique benefits of baseball's obsession with statistics and tradition has positioned it as an oft-employed proxy measure, not just in management scholarship but in economics and social science studies as well (Cashmore 2000; Ruggiero et al., 1997; Grusky 1963; Horowitz 1994a; Horowitz 1994b; Horowitz 1997; Porter and Scully 1982; Prisinzano 2000; Singell 1993; Scully 1989; Scully 1995; Konig 2003). Grusky used baseball managers to explain the affects of managerial succession on organizational effectiveness. He explains, "Baseball teams and, in fact, most professional sports clubs offer the research advantages of public records of team personnel and team performance" $(1963,22)$. This is an advantage in studies of the public sector because, if the goal is to most effectively test a manager's contribution to his or her organization, it is vital to employ data that can be compared over long periods of time and against other organizations with the same goals. "The structure of baseball organizations is such that ultimate responsibility for the performance of the team is almost always fixed on one position, that of field manager. At the same time, official authority is generally concentrated in this position" (Grusky 1963, 22). While it may not be fair to the field manager to have all of the responsibility, this observation fits in comfortably with the research question; do organizations that have frequent changes in management see more negative results in performance? 
Kahn argues that both public and private managers (in this case, baseball managers) must make hundreds of decisions each day, most having to do with subordinate performance $(1993,532)$. Kahn's posit correlates with the knowledge that decision-making is not an experience that focuses on the final moment, but a process of complex decisions made over a period of time (Simon 1960). However, is there more to the process than just monitoring performance? If managing an organization were nothing more than organizational monitoring, organizational performance would essentially be random, with managers making little, if any, impact. Change in performance indicators as a function of managerial change would be unlikely. Horowitz (1994a) refers to this as the "principal clerk" hypothesis, which is the economic theory that views managers as fungible "principal clerks." The "manager fungibility" case, Horowitz argues, is most pervasive under the following conditions: (1) tasks and decisions are repetitive; (2) managers have the same information and decision tools; (3) managers will be evaluated by those who would have used the same methods they used. To test his hypothesis, Horowitz employs James' (1986) Pythagorean Theorem of Baseball. While Horowitz' model of runs scored versus runs against is an appropriate measure, expanding it with the Runs Created model (which is articulated in the following section of this analysis) can give a more robust explanation, as the principal clerk theory does not control for individual players, either in terms of salary (a proxy for the market's (or nonrational bidding of the owner's) assessment of the individual players' performance) or in terms of the statistics themselves. The primary weakness of the fungible manager approach has to do with the one major change in baseball, namely, free agency, which has freed the player from team ownership, and provided for more lucrative owners to bid for and negotiate with the best (statistically speaking) players. ${ }^{3}$

Kahn (1993) observes that successful managers understand the strengths and weaknesses of their players, and know how and when to exploit and protect them. Successful managers find ways to control for the strengths and weaknesses of their players, as well as the strengths and weaknesses of their opponents.

For example, in the 2002 World Series, Mike Scioscia, manager of the Angels, chose to protect against the strength of Giants slugger Barry Bonds by walking him on nearly half of his plate appearances (13 walks and 17 official atbats). On the other hand, he chose to exploit Bonds' relatively weak mobility in the outfield by allowing base runners to take extra bases when the ball went into left field. Scioscia, while taking some of the fun out of the World Series for Barry Bonds, was making managerial decisions that he felt (and consequently turned out to be true) would put his team in the best position to win. This example reiterates the point that managers in baseball have many of the same duties and are put into many of the same positions to influence the performance of their organization as managers in the public sector.

How do organizations perform when they have frequent managerial turnover compared to organizations with more stable management? Again, Boyne and Dahya (2002) and Hill (2005) argue that changing managers will have an affect on the performance of an organization. If Hill's prediction is correct and a negative effect on performance when managers are changed (using public school superintendents) is evident, and if the argument of public manager/baseball manager similarities is reasonable, then it stands to reason that we would see similar results from the baseball data. Furthermore, if organizations replace top managers without allowing for some transition period in which all of the previously-articulated relationships can be forged and regimes can be adapted, performance is likely to continue to be below predicted values.

There have been myriad tests using myriad methodologies that attempt to delineate the manager/performance relationship. ${ }^{4}$ Porter and Scully (1982) is one of the first studies to quantify the production function of managers, and in this case, baseball managers. The authors find that managerial skill "contributes very substantially to the production function" (642). Prisinzano (2000) tests the Matching Hypothesis, which says that manager and the organization have to be a good fit. The results present evidence that the quality of the team-manager match is an important determinant of overall team performance. Thus, Porter and Scully build the production function, and Prisinzano's analysis implies the importance of chemistry, which no doubt is part of that function, it is to be expected that experience may have some relationship between managing players and managing ball clubs. Singell,

\footnotetext{
${ }^{3}$ This is why the Yankees and Cubs can assemble the very best players, while the Pirates and Brewers are left with players who have yet to show statistical prowess. Thus, if one of the manager's responsibilities is to, in fact, retain peace in the clubhouse as well manage the day-to-day strategies of the team, as Horowitz asserts, then the fungible manager argument deserves some expansion of statistical analysis.

${ }^{4}$ As the primary focus of this analysis is Major League Baseball, the presentation of the literature on sports and performance is constrained to baseball literature. To be sure, other sports are fairly represented in this field of study. See Koning 2003 as a sample of management/performance in the world of soccer.
} 
Jr., (1993) tests the link between compensation and performance vis-à-vis managerial experience, both at the team and the individual level. He finds that holding team skills constant, the probability of winning depends upon the manager, and in fact, when underperforming players are traded to "better-trained" managers, their performance improves.

Horowitz (1994b, 1997) uses the Pythagorean theorem of baseball to evaluate major league managers, which states that the ratio of wins to losses can be approximated through an examination of the runs scored of the team versus the runs scored of the opponent, and concludes that there are quantifiable differences in managerial abilities. While Horowitz makes a convincing argument, Ruggiero et al. $(1997)^{5}$ claim that while this is not an unreasonable approach to studying wins and losses, it is not an appropriate measure when studying managerial influence. ${ }^{6}$

Scully (1995) addresses the issue of managerial succession when he states, "The length of managerial tenure in professional team sports ought to be linked to coaching quality" (146). He argues that managerial termination is a function of the team's standing or relative rank to other clubs in the same league. The theory being that teams that finish first or second in their divisions will more likely retain their managers than those who finish ranked lower, relative to the competition. If then, replacement yields greater wins (increased performance) then changes are rational, and stands then in opposition to the fungible principal clerk theory. If records do not improve, termination or replacement is irrelevant. While Scully's analysis provides evidence for his resulting statement, the analysis is oversimplified so as not to control for many of the conditions that the author assumes away, specifically by constraining the analysis to one year. By aggregating the individual player statistics to the team level, as is done in this investigation, the analysis can be expanded beyond the simple one year analysis to determine short and long term effects of succession.

\section{Hypotheses}

Two sets of regressions were employed to test the hypotheses. The first test deals with the number of runs scored. In order to win games, teams must outscore their opponents. Hitters are not responsible for roster changes or calling pitches. Managers are. Ultimately hitters are responsible for scoring runs. Thus, a "good" manager ought to be able to position his players in such a way that they can score runs and win games. Bill James (1988) has developed a method for determining how much effort a manager ought to be able to get out of his team. This measure is called the "Runs Created" (RC) measure. Where it is the responsibility of the individual player to score runs, this measure comprehensively predicts if a team performs up to the level they should, given the players they have.

The Runs Created method offers a way to control for the players on the team, and the general manager's influence on salary, contracts, etc. James' method controls for players that a team has by comparing the players' total RC to the team's actual outputs. For example, it would hardly be fair to compare the free-spending Los Angeles Dodgers of 1988 ( $\$ 15.2$ million combined salaries) to the 1988 Minnesota Twins ( $\$ 8$ million combined salaries). However, if each team is compared to itself, we see that the difference between the predicted runs for the Dodgers and the actual runs was 38 runs in the positive direction, while the Twins under-produced by 26 runs. Factoring in all of the different ways a player can contribute to the scoring of runs is a reflection on how effective the manager is in getting his team to outscore the opposition; in other words, managing his players.

James's method considers some of the factors that managers have real control over, namely, sacrifice bunts, stolen base attempts, and total at-bats. The Runs Created statistic is:

$\mathrm{RC}=(\mathrm{H}+\mathrm{BB}+\mathrm{HBP}-\mathrm{CS}-\mathrm{GIDP}) *(\mathrm{~TB}+(.26(\mathrm{BB}-\mathrm{IBB}+\mathrm{HBP}))+(.52(\mathrm{SH}+\mathrm{SF}+\mathrm{SB}))) /(\mathrm{AB}+\mathrm{BB}+\mathrm{HBP}+\mathrm{SH}+\mathrm{SF})$.

Where

$\mathrm{H}=$ Hits

$\mathrm{BB}=$ Walks

\footnotetext{
${ }^{5}$ Horowitz and Ruggiero et al. exchange in a lively debate as to the merits of the Pythagorean Theorem. To determine the merits of each, we would direct the reader to the cited literature.

${ }^{6}$ In fact, Bill James himself (1988) agrees that using the Runs Created model he develops is a more appropriate technique when determining the influence of aggregated individual performances.
} 
$\mathrm{HBP}=$ Hit By Pitch

$\mathrm{CS}=$ Caught Stealing

GDIP= Grounded Into Double Play

$\mathrm{TB}=$ Total Bases

$\mathrm{IBB}=$ Intentional Walks

$\mathrm{SH}=$ Sacrifice Hits

$\mathrm{SF}=$ Sacrifice Fly

$\mathrm{SB}=$ Stolen Base

$\mathrm{AB}=\mathrm{At}$ Bat

If a player is to be judged on his ability to score runs, it is incomplete to only look at batting average and on-base percentages. The Runs Created formula looks at additional aspects of hitting that aid a player's ability to score runs. The first term, (H+BB+HBP-CS-GIDP), includes the traditional pieces for figuring offensive output, or an adjustment to the on-base percentage. Simply put the first term factors the number of times a player gets on base subtracted from the number of times he gets himself or somebody else off. The second term is where much of the meat of the formula is included. The total bases term, $(\mathrm{TB}+(.26(\mathrm{BB}-\mathrm{IBB}+\mathrm{HBP})))+(.52(\mathrm{SH}+\mathrm{SF}+\mathrm{SB}))$, factors other ways that managers can put players on base and position them to score runs. This considers intentional walks as well as sacrifices, in other words, moving runners through the bases. It also includes the standard figure for the league batting average (.260). The total bases term incorporates the slugging percentage into the Runs Created formula. The final term, $(\mathrm{AB}+\mathrm{BB}+\mathrm{HBP}+\mathrm{SH}+\mathrm{SF})$, is an adjustment to the on-base percentage of the hitter. Presumably, if the manager can get the players to score more runs than they are predicted to score, that is, whether the team's actual runs exceed the calculated $R C$, then the manager has had an impact on the team. Conversely, if actual RC is less than the predicted RC, then we can argue that the manager has had a negative influence on performance. They are still affecting performance.

The mathematical model employed for testing these hypotheses is:

Where

$$
R S_{t}=\alpha_{1}+\beta_{1} M C_{1}+\beta_{2} F C_{2}+\beta_{3} R C_{3}+\beta_{4} M Q_{4}+\beta_{5} M V P_{5}+\beta_{6} M O Y_{6}+\varepsilon_{t}
$$

$$
\begin{aligned}
& \mathrm{RS}=\text { Runs Scored } \\
& \mathrm{MC}=\text { Managerial Change } \\
& \mathrm{FC}=\text { Frequency of Managerial Change } \\
& \mathrm{MQ}=\text { Runs Scored-Runs Created } \\
& \mathrm{MVP}=\text { Most Valuable Player (two/year) } \\
& \mathrm{MoY}=\text { Manager of the Year (two/year) } \\
& \varepsilon=\text { Error Term } \\
& \beta=\text { Some estimable parameter }
\end{aligned}
$$

The data are organized chronologically by teams, with lagged dependent variables to account for time. ${ }^{7}$ Runs Scored is the dependent variable and is analogous to organizational performance. Teams set performance standards that will reflect wins. Scoring runs is the most obvious and easily measurable performance indicator that leads to wins. Clearly, a team must outscore its opponent to win, which allows the team to progress towards its primary goal of winning games. Not all teams set making the playoffs or winning the World Series as performance indicators. If this was the performance standard the industry expected, then only 8 of 32 (or 1 of 32 , as the case may be) teams per year would have achieved their performance standards. No, a reasonable indicator for the purposes of this test is using the number of runs scored as a dependent variable. The independent variables are managerial change, and frequency of managerial change (see Table 1).

The second test is designed to test a manager's impact on the organization by incorporating scoring runs and how these runs relate to amassing wins. A team can be expected to win more games if that team can score more runs than it gives up. The test of a manager's ability to get his team to outscore the opponents is measured in the same

\footnotetext{
${ }^{7}$ The data have been scrutinized by standard diagnostic tests for heteroskedasticity and autocorrelation. The data were run using dummy variables for each year, as well as testing for robust standard errors.
} 
manner as the Runs Scored variable. Bill James (1988) again provides a formula that tests the concept of predicting a team's winning percentage, or "Offensive Winning Percentage" or OWP. The breakdown is as follows:

1. Figure runs created per game

2. Divide that number by the league average (LA) of runs/game

3. Square the result

4. Divide that figure by one plus itself

The equation looks like this:

$((\text { RC/game }) /(\text { LA/runs/game }))^{\wedge} 2 / 1+((\text { RC/game }) /(\text { LA/runs/game }))^{\wedge} 2$

This equation will give the Offensive Winning Percentage of each team for each year, which is a predicted value, similar to the Runs Created value. This predicted value could then be compared against the actual winning percentage of the team to determine if producing more runs per game will lead to a better winning percentage. If the manager can get his team to win more games by outscoring their opponents by a wider margin than was predicted, then it can be argued that the manager is indeed affecting the outcomes of the organization.

The model is as follows:

$$
W P_{t}=\alpha_{1}+\beta_{1} M C_{1}+\beta_{2} F C_{2}+\beta_{3} M Q W P_{3}+\beta_{4} M V P 4+\beta_{5} M O Y_{5}+\varepsilon_{t}
$$

Where

$$
\begin{aligned}
& \text { WP = Winning Percentage of the Team } \\
& M C=\text { Managerial Change } \\
& \mathrm{FC}=\text { Frequency of Managerial Change } \\
& \mathrm{MQWP}=\text { Winning Percentage }- \text { Offensive Winning Percentage } \\
& \mathrm{RC}=\text { Runs Created } \\
& \varepsilon=\text { Error Term } \\
& \beta=\text { Some estimable parameter }
\end{aligned}
$$

Employing Runs Scored and Winning Percentage as dependent variables will allow for the following hypotheses to be tested;

\section{H1. Change in baseball managers will affect the performance (runs scored) of the team they manage. Hla. Frequent managerial succession will have significant, negative effect on organizational performance.}

H2. Change in baseball managers also affects the winning percentage of their team. H2a. Frequent managerial succession will have significant, negative effects on winning percentage.

\section{Results}

In testing the first model using time-series data, it is clear that there is a relationship between the baseball manager and his affect on the organization (See Table 2). Clearly, with respect to both runs scored and winning percentage, the managerial quality term (MQ) was positive and significant. This result implies that when controlling for the many factors that influence the scoring of runs and winning percentage, managers have the ability to influence performance. This is an important finding in that it establishes the basic logic of succession. If managers did not influence the year-to-year performance of the organization, what logic would we see in managerial change affecting performance?

Also apparent in the results is, in both the runs scored and winning percentage models, managerial change had a negative and significant relationship, signifying that in the year following a succession event, the team won fewer games and scored fewer runs. In short, the relationship between managerial change and organizational performance

\footnotetext{
${ }^{8}$ The assumption with this statement is that owners have a presumptive objective to win, and that wins correlate to profit maximization. Others have pointed out clearly that this is not necessarily the case. For example, the Cubs fill Wrigley Field irrespective of win total, and the George Steinbrenner fires managers irrespective of, well, anything. While this point is of importance to causes of managerial succession, it is less germane to an analysis of the effects of succession.
} 
was negative. This result endorses the short-term implications of managerial succession that have permeated the literature.

Interestingly, the test of frequency yielded positive and significant results (Table 2). This was an unexpected result as the theory argues that more succession would lead to lower performance. On average, there were nearly seven managerial changes per team during the twenty five year test period (mean score of 6.88). This result seems to contradict the hypothesis of frequent change leading to lower performance, both in runs scored and winning percentage. In fact, the implication from the analysis is that organizations with more change over longer periods have better performance, after controlling for the down year following the change. This is, indeed, a counterintuitive empirical result.

The explanation seems to lie in the nonlinear relationship between performance and turnover. In order to explore these unusual finding, a test for non-linearity was performed by squaring the frequency of change value and found the result to be negative and significant, confirming the theoretical expectation of frequent changes, albeit not exactly how the theory was laid out (See Table 3). This result implies a point of diminishing returns. Some turnover in top management will lead to better results, but you can have too much of a good thing. After a time, the organization reaches a point of diminishing returns, and the performance of the organization begins again to drop.

Included in the model were two dummy variables; the Manager of the Year from each league as well as each league's Most Valuable Player. These factors were in the predicted direction, in fact teams with Managers of the Year could generate 38 more runs per season and raise their winning percentage by $3 \%$ (or approximately 5 games), and teams with the Most Valuable Player generate nearly 55 more runs on average, and raised their winning percentage by nearly $4 \% .{ }^{9}$ Clearly then managers tend to perform better when they have developed some stability with their teams, lending support for the theory of managerial succession in terms of frequency. ${ }^{10}$

\section{Conclusion}

The discussion here centers on the public manager and managerial change. The findings presented in this analysis generally support the theory of public managerial succession, although the results are generated from baseball managers rather than public managers.

It is clear that managers make a difference on the actual performance of the organization. The "runs scored" measure and the "offensive winning percentage" measure, when compared together give a very good indication of the value of the manager to the team. Also apparent is that managerial tenure and stability have positive impacts on performance. Organizationally speaking, some change is to be desired; however this relationship is not necessarily linear. In fact, too much change leads to a drop in performance, and even the savviest of managers cannot overcome this dilemma. The nonlinear affect of frequent change is evident in this analysis.

The results suggest that managers do more than simply monitor the work behavior of their subordinates. They have a direct affect on their organization. Using baseball numbers to determine this managerial/organizational relationship allows for research in an environment where there are multiple organizations (teams) with the same performance indicators (wins and runs).

The results and conclusions are implicitly giving the manager credit for the performance of players that may come from a player's personal desire, external motivating factors (salary bonuses, trips to the All-Star game, commercial contracts to name a few), or the effects of other coaches (Kahn, 1993). There is also the concept of "team chemistry" which is extremely difficult to measure, but potentially has some impact on the outcome of the

\footnotetext{
${ }^{9}$ Only five times out of forty eight awards did the Manager of the Year not manage that team in the previous year. They were Billy Martin (Oakland, 1980), Hal Lanier (Houston, 1986), and Dusty Baker (San Francisco, 1993) and Joe Torre (New York Yankees, 1996) and Tony Perez (2003).

${ }^{10}$ However, not all of the variance is predicted by the OWP term. There may be other factors that were not within the scope of this study. These factors could be, but are not limited to the fact that some games are blowouts while others are one-run affairs, and if a particular team loses the one-run games but wins the blowouts, it is possible to have a negative MQ score and still have a winning record. For example the 1979 Cleveland Indians gave up 51 more runs than they scored yet they still finished a game over .500.
} 
organization. ${ }^{11}$ Finally, managerial changes are frequently accompanied by other coaches (i.e., bench coach, hitting and pitching coaches, base coaches). The impact of the replacement coaches on performance is also credited to the manager, which may be a weakness of the analysis, and is a potential area of continued research. These same types of concerns exist in the public sector, however, and are concerns that public managers are likely to deal with (maybe not commercial contracts or All-Star games, although non-monetary awards and recognition are an important motivating factor for public servants, as well as managing or replacing low and mid-level managers (Hill, 2005a)).

Even though baseball managers are not public managers, they maintain the same goal, namely, maximizing their outputs with the resources available. It seems reasonable given the empirical analysis that frequency of managerial change serves to strengthen the theory of managerial succession articulated throughout. Managers do affect the outcomes of the organization, and we see that managerial succession does indeed, have a nonlinear relationship with performance.

\footnotetext{
${ }^{11}$ I tend to agree, however, with Paul DePodesta, general manager for the Los Angeles Dodgers, when he said, "chemistry is a three-game win streak" when asked why he traded clubhouse and fan favorite Paul LoDuca to the Florida Marlins for Hee Sop Choi, Brad Penny and cash, which would allegedly disrupt the clubhouse chemistry at the time. Chemistry may not be measurable because chemistry may not exist.
} 
This is an author-produced, peer-reviewed version of this article. The final, definitive version of this document can be found online at The Social Science Journal (doi: 10.1016/j.soscij.2008.11.001) published by Elsevier. Copyright restrictions may apply.

\section{References}

Agranoff, Robert, and Michael McGuire. 2003. Collaborative public management: New strategies for local governments. Washington, DC: Georgetown University Press.

Allen, Michael Patrick, Sharon K. Panian, Roy E Lotz. 1979 "Managerial Succession and Organizational Performance: A Recalcitrant Problem Revisited.” Administrative Science Quarterly, Vol. 24, Issue 2, $167-180$.

Bogason, Peter, and Theo Toonen. 1998. Introduction: Networks in public administration. Public Administration 76: 205-227

Boyne, George, and Jay Dahya. 2002. Executive succession and the performance of public organizations. Public Administration 80: 179-200.

Bressers, Hans, Laurence J.O’Toole Jr., and J. Richardson. 1995. Networks for water policy: A comparative perspective. London: Frank Cass.

Cashmore, Ellis. 2000. Making sense of sports. London and New York: Routledge Press.

Cook, Brian J. 1996. Bureaucracy and Self-Governmen: Reconsidering the role of public administration in American politics. Baltimore: Johns Hopkins University Press.

Denhardt, Robert B. 2000. Theories of Public Organization. Fort Worth: Harcourt Brace Publishers.

Forman, Sean. 2000. "Baseball-Reference.com.” http://www.baseball-reference.com/ October 21, 2002.

Gamson, William A., and Norman A Scotch. 1964. "Scapegoating in Baseball." American Journal of Sociology. $70: 1,69-72$.

Greanier, Todd. 2001. “The Baseball Archive.” http://baseball1.com/c-stats.html October 21, 2002.

Goldsmith, Stephen, and William D. Eggers. 2004. Governing by network: The new shape of the public sector. Washington, D.C.: Brookings Institution Press.

Grusky, Oscar. 1963. "Managerial succession and organizational effectiveness.” American Journal of Sociolog. 69:1, 21-31.

Hill, Gregory C. 2005. "The effects of managerial succession on organizational performance." Journal of Public Administration, Research, and Theory, 15:4, $\quad$ 585-598.

Hill, Gregory C. 2005a. Unpublished survey of the Idaho Department of Health and Welfare.

Horowitz, Ira. 1994a. “On the manager as principal clerk.” Managerial and Decision Economics, Vol. 15, 413-419.

Horowitz, Ira. 1994b. "Pythagoras, Tommy Lasorda, and me: On evaluating baseball managers." Social Science Quarterly, Vol. 75, 187-194.

Horowitz, Ira. 1997. "Pythagoras’s petulant persecutors.” Managerial and Decision Economics, Vol. 18, 343-344.

Huber, John D., and Charles R. Shipan. .2002. Deliberate Discretion? Cambridge: Cambridge University Press.

James, Bill. 1988. The Bill James Baseball Abstract 1988. New York: Ballantine Books.

James, Bill. 2001. The New Bill James Historical Baseball Abstract. New York: Free Press. 
This is an author-produced, peer-reviewed version of this article. The final, definitive version of this document can be found online at The Social Science Journal (doi: 10.1016/j.soscij.2008.11.001) published by Elsevier. Copyright restrictions may apply.

Kahn, Lawrence M. 1993. "Managerial Quality, Team Success, and Individual Player Performance in Major League Baseball.” Industrial and Labor Relations Review, Vol. 46, Issue 3, 531-547.

Klijn, E. 1996. Analyzing and managing policy processes in complex networks: A theoretical examination of the concept policy network and its problems. Administration and Society 28: 90-119.

Koning, R. H. 2003. "An econometric evaluation of the effect of firing a coach on team performance.” Applied Econometrics, Vol. 35, 555-564.

Lynn, Laurence E., Jr. 1995. Public Management as Art, Science, and Profession. New Jersey: Chatham House.

Lynn, Laurence E., Jr., Carolyn J. Heinrich, and Carolyn J. Hill. 2001. Improving governanace: a new logic for empirical research. Washington, DC: Georgetown University Press.

Mandell, Myrna P. (Ed). 2001. Getting results through collaboration: Networks and network structures for public policy and management. Westport, CT: Quorum Books.

Meier, Kenneth J. and Laurence J. O'Toole, Jr. 2002. "Public Management and Educational Performance: The Impact of Managerial Networking." Public Administration Review.

Meier, Kenneth J., and Laurence J. O’Toole, Jr. 2002a. Public management and organizational performance: The impact of managerial quality. Journal of Policy Analysis and Management 21: 629-643.

------. 2005. Managerial networking: Issues of measurement and research design. Administration and Society 37 : $523-541$.

Milward, H.Brinton, and Keith Provan. 1998. Principles for controlling agents: The political economy of network structure. Journal of Public Administration Research and Theory 8: 203-211.

------. 2000. Governing the hollow state. Journal of Public Administration Research and Theory 10: $359-379$.

Morgan, Gareth. 1998. Images of Organization. Thousand Oaks: Sage Publishing.

Osborne, David and Peter Plastrik. 1997. Banishing Bureaucracy. Reading, Mass: Addison-Wesley.

Osborne, David and Ted Gaebler. 1992. Reinventing Government. Reading, Mass: Addison-Wesley.

O’Toole, Jr., Laurence J. 1997. Treating networks seriously: Practical and research-based agendas in public administration. Public Administration Review 57: 45-52.

O'Toole, Laurence J., Jr, and Kenneth J. Meier. 1999. "Modeling the Impact of Public Management: Implications of Structural Context." JPART 9: 505-526.

O'Toole, Laurence J., Jr, and Kenneth J. Meier. 2000. "Networks, Hierarchies, and Public Management: Modeling the Nonlinearities," in Governance and Performance: New Perspectives. Carolyn J. Heinrich and Laurence E. Lynn, Jr., eds. 2000. Washington, DC: Georgetown University Press

Peterson, J., and L.J. O'Toole. 2001. Federal governance in the US and the EU: A policy network perspective. In The federal vision: Legitimacy and levels of governance in the US and the EU, ed. K. Nicolaidis and R. Howse, 300-344. Oxford, UK: Oxford University Press.

Porter, Philip K., and Gerald W. Scully. 1982. "Measuring managerial efficiency: The case of baseball.” Southern Economic Journal, Vol. 48, 642-650. 
Prisinzano, Richard. 2000. "Investigation of the matching hypothesis: The case of Major League Baseball." Journal of Sports Economics, Vol 1, 277-298.

Rainey, Hal G. 1997. Understanding and Managing Public Organizations. San Francisco: Jossey-Bass.

Rhodes, R. A. W. 1997. Understanding governance: Policy networks, reflexiivity, and accountability. Buckingham, UK: Open University Press.

Ruggiero, John, Lawrence Hadley, Gerry Ruggiero, and Scott Knowles. 1997. "A note on the Pyghagorean Theorem of baseball production." Managerial and Decision $\quad$ Economics, Vol. 18, 335-342.

Scully, Gerald W. 1989. The business of Major League Baseball. Chicago, Ill: University of Chicago Press.

Scully, Gerald W. 1995. The market structure of sports. Chicago, Ill: University of Chicago Press.

Simon, Herbert A. 1960. The New Science of Management Decision. New York: Harper \& Brothers.

Singell, Larry D. 1993. "Managers, specific human capital, and firm productivity in Major League Baseball." Atlantic Economic Journal, Vol. 21, 47-59.

Taylor, Frederick. 1911. The principles of scientific management. Mineola, NY: Dover Publications.

Weber, Max. 1946. In From Max Weber: Essays in sociology. (Originally published in German in 1922), Translated and edited by H.H. Gerth and C. Wright Mills. New York: Oxford University Press.

Wilson, Woodrow. 1887. “The Study of Administration,” Political Science Quarterly, Vol. 2, 197-222. 


\section{Table 1:}

\section{Descriptive Statistics}

$\underline{\text { Variable }}$

Runs Scored

Winning Percentage

Runs Created

Offensive Winning Percentage

Managerial Change

Frequent Change

Frequent Change Squared

Managerial Quality (Runs)

Managerial Quality (Winning Percentage)

$\begin{array}{lcccc}\text { Mean } & \underline{\text { Min }} & \underline{\text { Max }} & \text { Std. Dev. } \\ 713.06 & 329 & 1009 & 108.02 \\ 0.502 & 0.265 & 0.716 & 0.069 \\ 714.64 & 326 & 1013 & 109.04 \\ 0.499 & 0.283 & 0.645 & 0.059 \\ 0.313 & 0 & 1 & 0.464 \\ 6.88 & 3 & 11 & 2.27 \\ 52.51 & 9 & 121 & 30.44 \\ -1.58 & -83.36 & 75.22 & 23.70 \\ 0.0024 & -0.180 & 0.265 & 0.065\end{array}$

$\underline{\text { Mean }} \underline{\text { Min }} \underline{\text { Max }} \underline{\text { Std. Dev. }}$

$\begin{array}{llll}713.06 & 329 & 1009 & 108.02\end{array}$

$\begin{array}{llll}0.502 & 0.265 & 0.716 & 0.069\end{array}$

$\begin{array}{llll}714.64 & 326 & 1013 & 109.04\end{array}$

$\begin{array}{lll}0.0024-0.180-0.265 & 0.065\end{array}$ 
Table 2. Effect of Managerial Succession on Runs Scored and Winning Percentage

\begin{tabular}{|c|c|c|}
\hline & Runs Scored & Winning Percentage \\
\hline Managerial Change & $\begin{array}{c}-12.57 * * \\
(2.11)\end{array}$ & $\begin{array}{c}-.0106^{* *} \\
(2.54)\end{array}$ \\
\hline Frequency of Change & $\begin{array}{l}7.04 * * \\
(3.59)\end{array}$ & $\begin{array}{c}.0046^{* * *} \\
(3.63)\end{array}$ \\
\hline MQ(RS-RC) & $\begin{array}{c}.3504 * * \\
(2.99)\end{array}$ & $\begin{array}{l}.8171 * * \\
(23.53)\end{array}$ \\
\hline Most Valuable Player & $\begin{array}{c}53.62 * * \\
(6.01)\end{array}$ & $\begin{array}{c}.0387 * * \\
(6.70)\end{array}$ \\
\hline Manager of the Year & $\begin{array}{c}36.11 * * \\
(3.99)\end{array}$ & $\begin{array}{c}.0313 * * \\
(5.45)\end{array}$ \\
\hline Constant & $\begin{array}{c}733.97 * * \\
(33.90)\end{array}$ & $\begin{array}{l}.4862 * * \\
(34.73)\end{array}$ \\
\hline Observations & 646 & 646 \\
\hline R-squared & .6311 & .5703 \\
\hline Adjusted R-squared & .6155 & .5498 \\
\hline $\begin{array}{l}\text { Note: } \\
\text { t-scores in parentheses } \\
* \text { Significant at the } .10 \text { level } \\
* * \text { Significant at the } .05 \text { level }\end{array}$ & & \\
\hline
\end{tabular}


Table 3. Effect of Managerial Succession on Runs Scored and Winning Percentage Nonlinear Effects

\begin{tabular}{|c|c|c|}
\hline & Runs Scored & Winning Percen \\
\hline Managerial Change & $\begin{array}{c}-11.73 * \\
(1.94)\end{array}$ & $\begin{array}{c}-.0096 * * \\
(2.31)\end{array}$ \\
\hline Frequency of Change & $\begin{array}{c}22.23 * * \\
(3.40)\end{array}$ & $\begin{array}{c}.0129 * * \\
(2.86)\end{array}$ \\
\hline Frequency of Change Squared & $\begin{array}{c}-1.32 * * \\
(2.71)\end{array}$ & $\begin{array}{c}-.0007 * * \\
(2.26)\end{array}$ \\
\hline MQ(RS-RC) & $\begin{array}{c}.3473 * * \\
(3.07)\end{array}$ & $\begin{array}{l}.8329 * * \\
(23.66)\end{array}$ \\
\hline Most Valuable Player & $\begin{array}{c}54.19 * * \\
(5.23)\end{array}$ & $\begin{array}{c}.0389 * * \\
(5.44)\end{array}$ \\
\hline Manager of the Year & $\begin{array}{c}38.11 * * \\
(3.64)\end{array}$ & $\begin{array}{c}.0315^{* *} \\
(4.21)\end{array}$ \\
\hline Constant & $\begin{array}{c}625.96 * * \\
(30.68)\end{array}$ & $\begin{array}{l}.4485^{* *} \\
(31.72)\end{array}$ \\
\hline Observations & 646 & 646 \\
\hline R-squared & .6371 & .5736 \\
\hline Adjusted R-squared & 6194 & .5528 \\
\hline $\begin{array}{l}\text { Note: } \\
\text { t-scores in parentheses } \\
* \text { Significant at the } .10 \text { level } \\
* * \text { Significant at the } .05 \text { level }\end{array}$ & & \\
\hline
\end{tabular}

